DE DE GRUYTER

OPEN
Journal of Intercultural Management

Vol. 5, No. 2, June 2013, pp. 5-16

DOI 10.2478/joim-2013-0007

\author{
Anna Lubecka \\ Institute of Public Affairs \\ Jagiellonian University
}

\title{
Employer branding - a dialogistic communication tool of a competitive employer
}

\begin{abstract}
The present article aims at discussing the value of employer branding, a relatively recent phenomenon in the field of company communication practices, which can be treated as an attempt to develop a dialogistic type of relationships between company employers and employees. The former use this communication strategy to attract quality workers and to retain the currently employed. For the latter it is the means to evaluate their employer by means of all kinds of suggestions, innovative remarks as well as comments, both positive and negative impacting the employer's image and reputation. As such employer branding may be treated as an important source of information for the employer about their management strengths and weakness, especially as far as their Public Relations (PR) practices are concerned. The author of the present article argues that employer branding can contribute significantly to the employer self-knowledge and verify their self-perception as well as serve to improve the image the company aims at creating only if the employer-employees communication becomes a dialogue. It implies that the communication between them must be founded on humanistic values which means that both parties treat each other with due respect, the information provided by the employees is neither manipulated nor distorted, and the employer acts as an active listener.
\end{abstract}

Key words: employer branding, communication, image, employer, values

Today we are faced with the pre-eminent fact that, if civilization is to survive, we must cultivate the science of human relationships. 


\section{Introduction}

Currently, an image constitutes one of the most vital pieces of information about a success of anC organization independently of its nature and profile of its activities. It has become equally important for market oriented companies and third sector organizations alike despite basic differences between them. In the case of the first sector companies, their image can be used both to enhance a company market position and make it more competitive while in the case of the third sector organizations, the most important prerequisite for them to create a positive image stems from their strong need to gain social approval, confidence, support and reliability, which in turn are crucial to make them effectively fulfill their mission. The same also applies to the public sector and its various institutions. They cannot carry out successfully their activities and serve the community needs if they have not gained social confidence and social approval.

Thus for all the organization the basic question is how to create their image and then manage it to meet the expectations of their employees, clients, stakeholders an all other subjects from their internal and external environment. The issue becomes especially challenging today when an organisation image does not depend merely on carefully planned, organised and monitored efforts of its Public Relation specialists and marketers but is concurrently created by many other institutions, people and events, often even without their direct involvement in the process. It is a sum total of many images, also the parallel ones, generated both voluntarily and involuntarily and communicated to a wide audience of an organization stakeholders as well as to the organization itself. The impact of parallel images on a final image may be very strong, both positive and negative, even destructive, especially if the two types of images are exclusive of each other and consequently result in a cognitive dissonance.

One of the groups of stakeholders who are able to create parallel images of an organistion are its own employees. They do it by means of employer branding which is a quite recent tool they have got at their disposal to communicate with their employer and evaluate, in both positive and negative way, the management principles and the company as a workplace. The first attempt to define it was made by T. Ambler and S. Barrow in 1996 in the Journal of Brand Management where they wrote that it is the package of functional, economic and psychological benefits provided by employment, and identified with the employing company. Following its commonly used definition by Brett Minchinton [2010, p. 37] from the Employer Brand Institute, employer branding is the image of the organization as a 'great place to work' in the minds of current employees and key stakeholders in the external market (active and passive candidates, clients, customers and other key stakeholders). The art and science of employer branding is therefore concerned with 
the attraction, engagement and retention of initiatives targeted at enhancing your company's employer brand. Its scope and its impact on both company employees and its potential hires has been also stressed in a more concise version of the definition proposed by G. Martin and P. Beaumont [2003, p. 12]. For them employer branding it is a company's image as seen through the eyes of its associates and potential hires.

Although there are numerous components of the employer branding, its foundations are human relationships and human emotions which get communicated to the employer as well as to the company external environment. Thus communication is at the heart of the process, which has been stressed by S. Lloyd [2002] who defines employer branding as sum of a company's efforts to communicate to existing and prospective staff what makes it a desirable place to work. The first ones want not only to become better informed about their employer but also to co-create their workplace by providing the company with a feedback and by suggesting changes and often innovative solutions to improve its management style. Assisted by electronic media which offer to them new communication tools, e.g. social media, blogs, web pages, etc. they have become empowered and extremely influential as far as the company image is concerned. Their critical comments, if truthful and authentic, are important pieces of information which should no be ignored by a company but used to start some remedial work beneficial for the company image and market position. For the future hires, employer branding which, as the term suggests, serves to make a company name a brand, helps to decide if they find the workplace attractive in the sense that it meets their expectations concerning not only the material values but also the non-material ones which are built into their job and the company culture. As argued by many employer brand practitioners [cf. S. Barrow, R. Mosle, 2005], an effective employer branding requires a clear Employee value proposition which allows to specify the values the company identifies with and bases its culture on. Only then employer branding can become an efficient tool first in the recruitment process attracting talents and then in retaining them. Thus it assists head hunters and Human Resources (HR) specialists in making them win the war on talents.

However, employer branding also offers a tool to manipulate a company image, to distort it and to disseminate information which is neither true nor accurate. For the same reason it can contribute to a company success it can also result in its failure. The strength of employer branding as both a constructive and destructive factor in creating and communicating a company image stems from, at least, two sources. Both of them are inherent features of virtual communication mediated by means of electronic media and are: firstly the communication extent which is practically unlimited and, secondly, the power 
of virtual communicators due to their anonymity and a lack of practically any censorship in the virtual context. These features of the employer branding communication invite more truthful, objective but also more critical opinions about its value at the same time drawing attention to the role of humanistic values in it.

The objective of the present article is to discuss the impact of employer branding which can be treated as a parallel image of an organization. Considering the role of interpersonal communication in it, the author posits that employer branding can become very effective in this function on the condition that the exchange of communication between the employer and the employees becomes a dialogue, which makes its participants respect basic human values. As such an effective employer branding touches upon a very important issue of a valuebased approach to shaping relationships between employer and employees, which has been clearly demonstrated by the influential study Build to last: Successful habits of visionary companies from the mid-1990s [Collins, Porras, 1995]. Its authors have clearly proved that the companies which consistently respected a distinctive system of values did much better than the company whose ethos was less well articulated and often divergent from everyday practice. It can be argued that this new management paradigm and company communication principles whose growing recognition can be observed recently, is a future trend. It will dominate not only employer branding but management styles because of significant changes in the needs and demands of employees, especially in civic and economically privileged societies whose number keeps growing [cf. Collins, Porras, 1995].

As already mentioned, employer branding is still a rather new phenomenon. The first book in the field was written in 2005. It was The Employer Brand: Bringing the Best of Brand Management to People at Work by Barrow and Mosley. The second one - Your Employer Brand - attract, engage, retain by B. Minchington - appeared in 2006. Employer branding has been also successfully recognized in Poland although the number of publications dealing with it is rather small, e.g. M. Kozłowski, Employer Branding. Budowanie wizerunku pracodawcy krok po kroku from 2011 evidences the situation. Most useful sources are Web pages which function as practical fora for employers as well as the employees who would like to use employer branding to strengthen their position on the labour market (e.g. Employer-branding.pl which deals with creating an employer image among Polish employers, Employer Branding Blog for those who have already got some experience in employer branding and Employer Branding Club). The English language literature is much richer for the simple reason that the term was coined in 1990 and introduced to the management audience by S. Barrow during an annual CIPD conference at Harrogate in the UK [Barrow, 1990]. 


\section{Employee Value Proposition (EVP) and an employer image}

A modern company, often transcultural and global, builds its social and market success on values which have undergone a deep evolution from mostly economic to humanistic. The change is a direct result of significant political, economic as well as socio-cultural transformations typical of postmodernism which have resulted in democratization of most areas in the world and a constantly growing welfare of its inhabitants. This, in turn, has impacted upon both the employees' perception of a company as an employer and their expectations about working conditions, economic benefits and non-economic advantages they will enjoy in it. Moreover, a company is seen not only as a market player interested in its own gains and profits but also a citizen concerned with values visible not only in its mission but, first of all, implemented in its management practices. As argued by Peter Drucker [1999, p. 29], management by values meant as humanistic values has become the biggest challenge for the $21^{\text {st }}$ century companies and a sine qua non condition of their effectiveness and success.

Value implementation has become a "hot" issue because it implies for most companies a challenge of how to make their own values, most often economic, compatible with the values of their employees, which tend to show a strong tendency towards humanization [cf. Sikorska, 2002]. As posited by Tandehill [in: “The Employment Value Proposition.", 2006] the key factors which influence an individual's decision to balance their career path in a company are apart from financial ones such as salary and benefits, relocation services, perquisites, career development, location, working hours, people at the workplace, independence, same value system, personal growth, management development, ongoing personal recognition, community service, etc. A good and attractive job offers a balance between the rewards and benefits that are received by an employee in return for their work for the employer and more exactly the skills, capabilities, innovativeness, engagement, experience, engagement they bring to the workplace. This new approach defined as the already mentioned Employee Value Proposition [cf. Minchington, 2010, 2006] changes the relationship between the employer and the employee. It is employee-centered and it is the employer's aim to communicate to their current or future workers the unique people-oriented policies, philosophy, culture and processes which demonstrate the company's commitment and management by humanistic values.

The two systems of values - of the employee and the employer - do not have to be identical but they must be close enough to avoid inner conflicts, dissatisfaction and often even a change of work by the former. If it happens it may often lead to staining the image of the employer and making prospectus hires choose other companies. There can be observed a growing awareness 
among employers world wide that their success, local and global, depends more then ever before on skilled, motivated, quality and value-driven employees [Barrow, Mosley, 2005, Mosley, 2007]. Hence, a company image has gained on importance as a tool to attract the best employees able to generate an organization intangibles which constitute its capital and true wealth much more than its purely economic resources. Modern organizations are based on knowledge, know-how and know-where, entrepreneurial spirit, intellectual and cultural potential of their workers. The change of their operational principles stems from very pragmatic prerequisites not to loose the position of a leader in the field. On the other hand it is also prompted by the employees' expectations towards their work and their employers, especially in the sphere of non-material values.

It may be observed a certain regularity in this respect: the more valuable the employer to the organization because of their symbolical capital [cf. Bourdieu, Passeron 1990], the bigger their expectations concerning the intangible qualities of their work, the stronger their need to have the company hold the same values as theirs own. Let me stress it once more that the Employment Value Proposition is mostly constituted by anti-consumption values, although the statement may sound controversial against the context of the culture of consumption. Only if the expectations are met, the employees stop treating their work merely instrumentally as a means to earn their living but feel loyal, engaged and inspired: their work matters to them and so does the employer. A company culture which respects values earns their respect for the company and its management. It also motivates them to stay with the company and when people truly connect to the organization and identify with it they go beyond the mediocre and generate its success. This is especially important today when good, creative and enterpreneurial employees are costly (usually the organization invests a lot in their formation), hard to find and even harder to retain (cf. the job of head hunters).

As Charles A. O’Reilly and Jeffrey Pfeffer [2000, p. 78] claim Aligning values, strategies, and management practices may be simple to understand and simple to talk about, but it is very difficult to actually implement. Hence a growing role of such an employer image which not only uses values but directly communicates to employees, other stakeholders and even competitors as well as the wide society that the values have been put into action, that they are not only known but also actively practiced by an organisation, its managers and workers alike who authentically identify with them. Such an image should evidence that the organization values and its mission statements such as integrity, quality, respect, high performance, teamwork, CSR, fairness, ethics etc. which are so easily declared are not just empty, meaningless words used because of fashions 
but they reflect a true organisational commitment. A value-based image of an organization should make it a competitive workplace and a most desirable employer who attracts the most beautiful minds and ethically full characters.

\section{Employer branding as a tool of a company parallel image}

Although employer branding is a rather new phenomenon - it started to be put in practice in 2001 at McKinsey's company - there can be noticed a growing awareness of its importance among both employers and employees alike. According to the survey by the Conference Board of 138 leading companies, only $40 \%$ claimed to be concerned with some form of employer branding [Dell, Ainspan, 2001, p. 28]. Tow years latter, in 2003, in another survey this time conducted by the Economist $61 \%$ of its global readers revealed their awareness of the concept among HR specialists and $41 \%$ among non-HR professionals. The numbers point out an astonishing "career" of the concept but also its usefulness as a communication tool to create a competitive employer.

As alreday mentioned it is based on employer-employees communication which aims at making an organization a brand employer and whose targets are potential and actual employees [cf. Armstrong, 2007]. Becoming a brand employer demands a long term management as well as an active participation of employees in the process [Mosley, 2007] where values are used to shape employee's perception of an organization as well as their own beliefs [cf. Collins, Porras, 1995].

Today more and more organizations have been actively using employer branding and exploring the information the employees provide them with to become more competitive on a workforce market where talented hires are difficult not only to find but mainly to retain.

Using the concept of a parallel image coined by a Polish specialist in the field, Wojciech Budzyński and carefully discussed in his book Wizerunek równoległy. Nowa szansa promocji firmy i marki (A parallel image. A new chance of a company and brand promotion) [2008], employer branding can be classified within this category. It is just one of the images parallel to the official images carefully made by PR officers and marketers in an organization. Parallel images result from communication activities of organization stakeholders, clients, workers, journalists, society, etc. Consequently, their constituents are both voluntarily or/and involuntarily spread messages, pieces of information, behaviours, associations, activities, organizational symbols, logos, slogans, colours, etc.

Roughly speaking, all kinds of verbal and non-verbal communication behaviours performed by people from an internal and external environment of an organization and coming from various sources result in an organisation image becoming a multidimensional mosaics, a colourful quilt where many threads can be detected. Values, especially humanistic ones, are its core 
components which account for its social recognition, criticism, disapproval or appreciation. Values have become today a battlefield where organizations fight for their image, their appreciation by their workers and other market actors as well as competitors.

\section{Employer-employees dialogue - a condition of a successful employer branding}

As one of the objectives of an organization image is to show a company as a nearly perfect employer and a highly desired workplace, the voice of the employees should be consideredas important in the process of its building. Hence the role of employer branding which is like a bridge between them as it offers a chance to the employers to learn how the organization is evaluated by employees. The employees, in turn, have been offered an opportunity to express their opinions about the organization, criticize it but also give a positive feedback when its policies meet their expectations.

Internet fora, blogs, employees' web pages and social media play an important role in this type of communication at least for two reasons. Firstly, it is their availability and secondly, their anonymity and safety. The latter offer their users an opportunity to be truthful and express their opinions more directly and clearly than in a face to face contact with managers and their immediate bosses even if invited to comment upon the organization management, its culture and the humanistic values which make companies differ from each other. In this sense such straightforward comments, even if critical are very important for rethinking and even redesigning the company policies. The employer should especially value the information which are sincere but at the same time contradictory as they deny the official information provided by their employer. Actually this is the worst which may happen as a lack of consistency between the image created by the employer and by their employees accounts not only for staining the company image but make the company loose its credibility.

Anonymity of the author of the comment as well as a lack of nearly any kind of censorship of the texts published in the Internet (if it does not contain any vulgar or obscene words and expressions and does not offend public persons) may also encourage dishonest opinions, both positive and negative, which manipulate facts and provide such distorted interpretations which are an ambivalent and blur the image of the company. It may also happen that the bloggers write lies give vent to their hurt ego and to take revenge for their own mistakes and failures which have nothing to do with company policies. Such negative messages may appear also because the micro-community of the employees involved in employer branding creates a feeling of togetherness among them and enhances their solidarity. They feel they can act unethically because the employer can neither identify nor join them unless invited. S/he can only read 
their massages and answer them or comment upon individual issues on their own blogs or web pages or by means of traditional communication media. S/he can also actively use the employees' observations by implementing subsequent changes in the organization management and informing the workers about their inspirational contribution to them. To make employer branding a success, it would be advisable to make the employees aware that their voice matters to their employer and is highly appreciated by management.

An ideal but not impossible form of the model of communication within the employer branding scheme uses the concept of partnership and equality as well as mutual respect and confidence. Thus it contributes to creating at the employees the feeling of loyalty, responsibility, engagement and commitment. As it delegates the mangers' power to workers it makes them part of the decision making process impinging upon management practices. Consequently, the employees feel more conscientious of the organization needs and objectives and they also become more active in contributing to the organization having them successfully met. We may venture saying that it is a symbolical act of turning employees into true shareholders which should be beneficial for all stakeholders of an organisation.

Truthfulness is another basic feature of proper and valuable communication. However, truth may be not only difficult to communicate but also to accept even if it is meant as a positive criticism whose aim is to improve the existing status quo. Modesty combined with knowledge, future orientation, imagination and openness help take criticism and make it a manger's visionary strength. It also demands the ability to think in terms of the good of the organization putting aside individual ambitions. Another difficulty stems from the fact that negative evaluation should never be personal but targeted at activities. It cannot serve to make up for a hurt ego but should be grounded in values. This explains why it needs a lot of courage to open a forum for critical discussions and why people so rarely do it in public without hiding in the virtual reality.

Referring to the above discussion, dialogistic communication, which is based on such values as partnership, truthfulness, respect and dignity seem to be the only possible choice for employer branding. Despite constituting a serious challenge for both the employer and the employee only dialogue can contribute to positive changes in the company management and become its asset [cf. Lubecka, 2010]. A dialogistic communication which is based on values implies that it will not be used to lie and to manipulate an organization image by disseminating false or incomplete information. As such it will become a useful source of knowledge for the employer as it will provide them with a feedback evaluating their own policy as well as the coherence between the organization values and the values of individual employees. 
Adialogistic exchange of information binds people together, empowers them, contributes to their dignity and self-worth. It puts into practice the concept of management by values as a well as participant management which better answer employees' expectations about their role in a modern organisation. Contemporary workers, especially in democratic and economically privileged countries do not want to be treated purely instrumentally but included in an organization. This, in turn, makes them feel proud of belonging to it and results in their more fully identify with its goals and policy. Consequently, they become strongly motivated to stay with it even if offered a more attractive contract elsewhere. Their emotional engagement and loyalty make them its advocates, marketers and civic PR officers. Their blogs or comments on web pages and in social media become then efficient tools of buzz marketing whose reliability is much bigger than of other kinds of organization-based promotional activities.

Employer branding realized as dialogistic communication offers a new instrument to the employers to motivate their employees, bind them to the organization, turn them into an organization asset and make them an even more efficient source of its intangibles. It also makes the employer directly benefit from it as they become competitive on the labour market.

\section{Conclusions}

Employer branding has got its newest versions employment branding and employee branding, which shows not only certain trends in management practices but also a practical value of these instruments. It can be also observed that a continually growing number of organizations use employer branding to successfully build their reputation as an employer, create their competitive image on the labour market and in the wide society and thus increase their intangibles.

Consequently, there can be observed a change in the employer's as well as employees' approach to employer branding. It stops to be treated as an employee's weapon to criticize an organisation and take revenge on it for its employees' unfriendly policy as its aim is to provide information and feedback to be used by the employer to become more attractive on the labour market. Thus it should not be feared by the employer who, in turn, should not ignore the anonymous voices of their employees to reevaluate the organisation management principles, HR policy and management by values. In the organizations which understand the value of the employer branding communication, it has become treated as an employer-employee dialogue. The information provided by employees-bloggers, users of social media, etc. is carefully analysed to re-examine the company strengths and weaknesses.

This approach sees employer branding as an opportunity to strive towards excellence and become a market winner. It also explores employer branding, 
especially its external manifestation, as buzz marketing, the cheapest and one of the most reliable means to advertise itself. It also reflects a new success philosophy of an organization how to become a strong brand: instead of focusing on internal branding initiatives, costly and uncertain about their results, it consists on supporting long term activities of employer brand management where employees' communication has got a dialogistic form.

\section{Bibliography}

Ambler, T and Barrow, S. (1996). The employer brand, In: Journal of Brand Management, Vol. 4, pp. 185-206.

Armstrong, M. (2007). Zarzq̨dzanie zasobami ludzkimi, Kraków: Oficyna Wolters Kluwer.

Barrow, S. (1990), 'Turning recruitment advertising into a competitive weapon', Paper delivered at the CIPD Annual Conference, Harrogate, UK.

Barrow, S., R. Mosley (2005), The Employer Brand: Bringing the Best of Brand Management to People at Work, John Wiley \& Sons, Chichester.

Bourdieu, P., J. C. Passeron, 1990. Reproduction in Education, Society and Culture, Sage Publications Inc.

Budzyński, W. (2008). Wizerunek równoległy. Nowa szansa promocji firmy i marki, Poltext, Warszawa.

Collins, J., Porras, J. (1995) Built to Last. Successful Habits of Visionary Company, Random House, UK.

Dell, D and Ainspan, N (2001), Engaging employees through your brand, Conference Board Report No. R-1288-01-RR, April, Conference Board, Washington, D.C.

Drucker, P. (1999). Management Challenges for the 21st Century, Harper Business, New York.

Kozłowski, M. (2011) Employer Branding. Budowanie wizerunku pracodawcy krok po kroku, Wolters Kluwer Polska - OFICYNA, Warszawa.

Lepsinger, R., Antoinette D. (1997) The art and science of 360 degree feedback, JosseyBass/Pfeiffer, San Francisco.

Lloyd, S. (2002), "Branding from the inside out," In: Business Review Weekly, Vol 24 No 10, pp. 64-66.

Lubecka, A. (2010) „Dialogue as an asset in managing an organisation”, [in:] B. Kożuch (ed.), Wspótczesne Zarządzanie. Kwartalnik Środowisk Naukowych i Liderów Biznesu, ss. 23- 33.

Martin, G. and Beaumont, P. (2003) Branding and People Management, CIPD Research Report, CIPD, London.

Minchington, B. (2010) Employer Brand Leadership - A Global Perspective, Collective Learning, Torrensville, Australia.

Minchington, B. (2006) Your Employer Brand - attract, engage, retain, Collective Learning, Torrensville, Australia. 
Mosley, R. (2007) "Customer experience, organisational culture and the employer brand', Journal of Brand Management, Vol 15, October Issue pp.123-134.

O’Reilly, Ch. A., J. Pfeffer. (2000). Hidden Values: How Great Companies Achieve Extraordinary Results with Ordinary People, Harvard Business School Press, Boston.

Sikorska, M. (2002), „Zmiany postaw Polaków wobec pracy: lęk przed bezrobociem i samorealizacja”, In: A. Jasińska-Kania, M. Marody (eds.), Polacy wśród Europejczyków. Wartości społeczeństwa polskiego na tle innych krajów europejskich, Warszawa: Wydawnictwo Naukowe Scholar, ss. 22 - 45.

„The Employment Value Proposition.” Article which introduces the original concept, by Tandehill Human Capital. Workspan Magazine 10/06 http://www.tandehill.com/ pdfs/Total-Rewards.pdf, accessed on 20 February 2012

\section{Netography:}

Employer branding, pl, http://www.employer-branding.pl/, accessed on 15 February 2012.

Employer branding BlogSpot, http://www.employer-branding.blogspot.com/, accessed on 15 February 2012.

Employer Branding Club, http://www.employerbrandingclub.com/, accessed on 20 February 2012.

Employer Branding Online, http://www.employerbrandingonline.com/, accessed on 20 February 20012.

Employer Brand, http://www.employerbrand.com/, accessed on 20 February 20012.

Personnel Today, http://www.personneltoday.com/Home/, accessed on 20 February 20012. 